Martin H. Kroll, Christopher R. McCudden

Endogenous Interferences in Clinical Laboratory Tests 


\section{Patient Safety}

Edited by

Oswald Sonntag and Mario Plebani

\section{Volume 5}


Martin H. Kroll, Christopher R. McCudden

\section{Endogenous \\ Interferences in Clinical Laboratory Tests}

Icteric, Lipemic and Turbid Samples

\section{DE GRUYTER}




\section{Authors}

Prof. Martin H. Kroll, MD

Quest Diagnostics

3 Giralda Farms

Madison, NJ 07940

Park

USA

E-mail: martinkroll500@gmail.com
Christopher R. McCudden, MD

University of Ottawa

Faculty of Medicine

Department of Pathology \& Laboratory Medicine

Ottawa, Ontario

Canada

E-mail: cmccudde@uottawa.ca

The book has 28 figures and 19 tables.

ISBN 978-3-11-026620-7

e-ISBN 978-3-11-026622-1

\section{Library of Congress Cataloging-in-Publication Data}

A CIP catalog record for this book has been applied for at the Library of Congress.

\section{Bibliographic information published by the Deutsche Nationalbibliothek}

The Deutsche Nationalbibliothek lists this publicatioin in the Deutsche Nationalbibliografie; detailed bibliographic data are available in the Internet at http://dnb.dnb.de.

(C) 2013 Walter de Gruyter GmbH, Berlin/Boston. The publisher, together with the authors and editors, has taken great pains to ensure that all information presented in this work (programs, applications, amounts, dosages, etc.) reflects the standard of knowledge and the time of publication. Despite careful manuscript preparation and proof correction, errors can nevertheless occur. Authors, editors and publisher disclaim all respondibility and for any errors or omissions or liability for the results obtained from use of the information, or parts thereof, contained in this work.

The citation of registered names, trade names, trade marks, etc. in this work dies not imoly, even in the absence of a specific statement, that such names are exempt from laws and regulations preotecting trade marks etc. and therefore free for general use.

Typesetting: PTP-Berlin Protago-TEX-Production $\mathrm{GmbH}$, Berlin Printing and Binding: Hubert \& Co. GmbH \& Co. KG, Göttingen Cover image: Comstock/Getty Images

@ Printed on acid-free paper

Printed in Germany

www.degruyter.com 
To my wife Ellen and children Allison, Lauren and Jonathan. Martin H. Kroll

To my wife Liesje and children Katie and Sam.

Christopher R. McCudden 
